\title{
Tubercle disease (Xanthomonas beticola) and other gall- malformed diseases of sugar beet roots: a review
}

\author{
Ewa Moliszewska ${ }^{1}$ - Małgorzata Nabrdalik ${ }^{1} \cdot$ Jacek Piszczek $^{2}$
}

Received: 28 April 2016/Accepted: 18 July 2016/Published online: 24 August 2016

(c) The Author(s) 2016. This article is published with open access at Springerlink.com

\begin{abstract}
The sugar beet (Beta vulgaris) is an important plant in agriculture and sugar industry, and it is widely cultivated in European countries. Getting proper raw material of sugar beets (roots) is a problem for agriculture. Some disease symptoms observed on sugar beet roots are atypical tumor-like deformations. The causative agent of these deformations is known in the old literature as Xanthomonas beticola. The disease's name in Poland is "tuberkuloza" and in the USA it refers to a description of a pocket disease-therefore we may consider those diseases to be the same. The clear description of $X$. beticola disease can be found in many phytopathological manuals printed in the past and nowadays. Symptoms of the disease were noted in Poland last year, and the preliminary data of the yield quality show that the quality of diseased roots is worse (less sugar content) than of healthy roots. For the proper disease diagnoses, the literature was searched and this searching lead us to conclusion that there is no simple way to recognize the causal organism in the field conditions, and we suppose that $X$. beticola does not exist.
\end{abstract}

Keywords Sugar beet $\cdot$ Gall $\cdot$ Xanthomonas beticola

Ewa Moliszewska

ewamoli@uni.opole.pl

1 Department of Technical and Environmental Sciences, Opole University, Opole, Poland

2 Regional Experimental Station, Institute of Plant Protection National Research Institute, Toruń, Poland

\section{Introduction}

The sugar beet (Beta vulgaris) is an important plant in the agriculture and in the sugar industry, and it is widely cultivated in European countries. When the first sugar factory was constructed and established at Cunern in Lower Silesia in 1801, cultivation of beet for processing started in the same year. Judging according to the current criteria, the first yield of sugar beet roots was not satisfactory, but it was the first step to development of sugar industry. Since that time sugar beet growers have been trying to obtain better and better quality of roots. This means higher sugar content and lower concentrations of amino nitrogen and sodium in cells of a root. At the same time, the aim was to increase the mass of roots obtained from a hectare of a sugar beet plantation; however, there are several possibilities to decrease the yield. The most important ones are diseases which can develop on roots and cause damage of tissues or lower either the sugar content or the sugar yield. Development of the sugar industry has led to obtain of a phytopathological knowledge, which resulted in the descriptions of sugar beet diseases and explaining their importance for the agriculture. The disease symptoms observed on sugar beet roots are unusual tumor-like deformations. The causative agent of these deformations is known in the old literature as Xanthomonas beticola. The disease symptoms take the form of multiple nodules grown on the upper surface of the roots. In extreme cases, roots with a large number of tumors are strongly deformed. Occasionally the disease can be confused with the tuberosity of the roots caused by Rhizobium radiobacter (syn. Agrobacterium tumefaciens). 


\section{Finding and detecting the tubercle disease and other gall-malformed diseases of sugar beet roots}

\section{Field observations}

In 2014 and 2015 we found sugar beet roots with severe gall symptoms. Roots with malformations were found for the first time in 2014 in Kłodawa, and they occurred rather occasionally (Fig. 1). In 2015 symptoms were noted in three localizations-again in Kłodawa (Fig. 2) in the same localization as in the previous year and in two localizations near Toruń (Kłodawa and Toruń are located in central Poland) (Fig. 3). These galls were irregular and developed on the whole root or on the upper part of it. If the whole roots were malformed, then the galls were bigger (Figs. 1, 2) than in the case of roots with symptoms on the upper part (root crown). If the symptoms developed only on the root crown, the galls observed were numerous and tiny (Fig. 3). The preliminary data of the yield quality showed that the quality of diseased roots was worse (less sugar content) than of the healthy roots (Table 1).

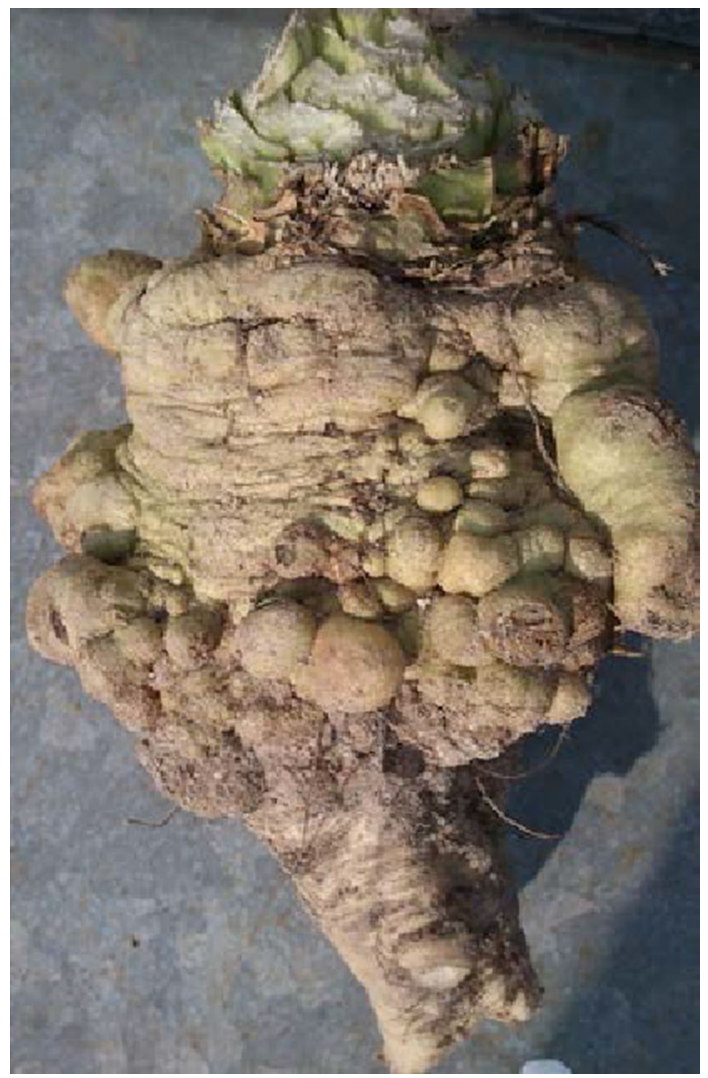

Fig. 1 Galls on sugar beet root observed in 2014 (Kłodawa, Poland)

\section{Laboratory investigations}

Bacteria present in deformed tissues have been isolated from infested roots. The following growth media specific for Xanthomonas type were applied: King B (KB), nutrient agar (NA), nutrient agar supplemented with $0.5 \%$ yeast extract (YNA), nutrient agar supplemented with $1.0 \%$ sucrose (SNA), yeast glucose agar (YGC), sucrose peptone agar (SPA) and malt extract agar (MEA). Incubation was conducted at $28{ }^{\circ} \mathrm{C}$, and observations of colony morphology were made every $24 \mathrm{~h}$ for 5 days. The time of colonies' appearance, their size, and morphology were recorded. The isolated bacteria were producing yellowcolored pigment, and their characteristic corresponded with the descriptions given by Benada et al. [2] and Bergey's Manual of Systematic Bacteriology [3]. Preliminary analyses were carried out on the basis of macroscopic and microscopic descriptions as well as biochemical reactions (oxidase, catalase, nitrate reduction, urease, $\mathrm{H}_{2} \mathrm{~S}$ from peptone, indole, acid production from: glucose, mannose, galactose, cellobiose, lactose, maltose and xylose). Gramnegative bacteria were tested with the use of API 20E and ID 32GN (bioMerieux, France) and the following groups were identified: Pseudomonas spp. and Pantonea spp. However, none of the isolated bacteria were identified as Xanthomonas which urged us to do some research about the disease. The initial laboratory tests did not prove the pathogenic character of bacteria toward beetroot, and thus a detailed study of other research papers was required as well as the search for reference bacteria strains. Further laboratory tests, however, had to be postponed until the following season to collect new infested plants.

Despite the detailed study we carried out, there is still one question to be answered: What is the cause of the malformation/galls on the roots shown in the pictures (Figs. 1, 2, 3)? The symptoms were classified as a tubercle disease of sugar beet (Xanthomonas gall) by experienced researchers and by sugar beet breeders, so we hope that it can be considered a correct diagnose, although the causal agent of it remains unclear.

\section{Current descriptions of Xanthomonas gall disease}

Our research on the problem of tubercle disease of sugar beet started from studying the literature, which showed us a great gap of knowledge about this disease. Firstly we classified the symptoms as the tubercle disease of sugar beet or Xanthomonas gall-which we found described in the current and in the old plant disease manuals. We discovered that the disease had not been reviewed and researched for many years, so all of its descriptions seemed to be a copy of the same first information. Pursuit of the information about the disease supposed to be caused by $X$. 


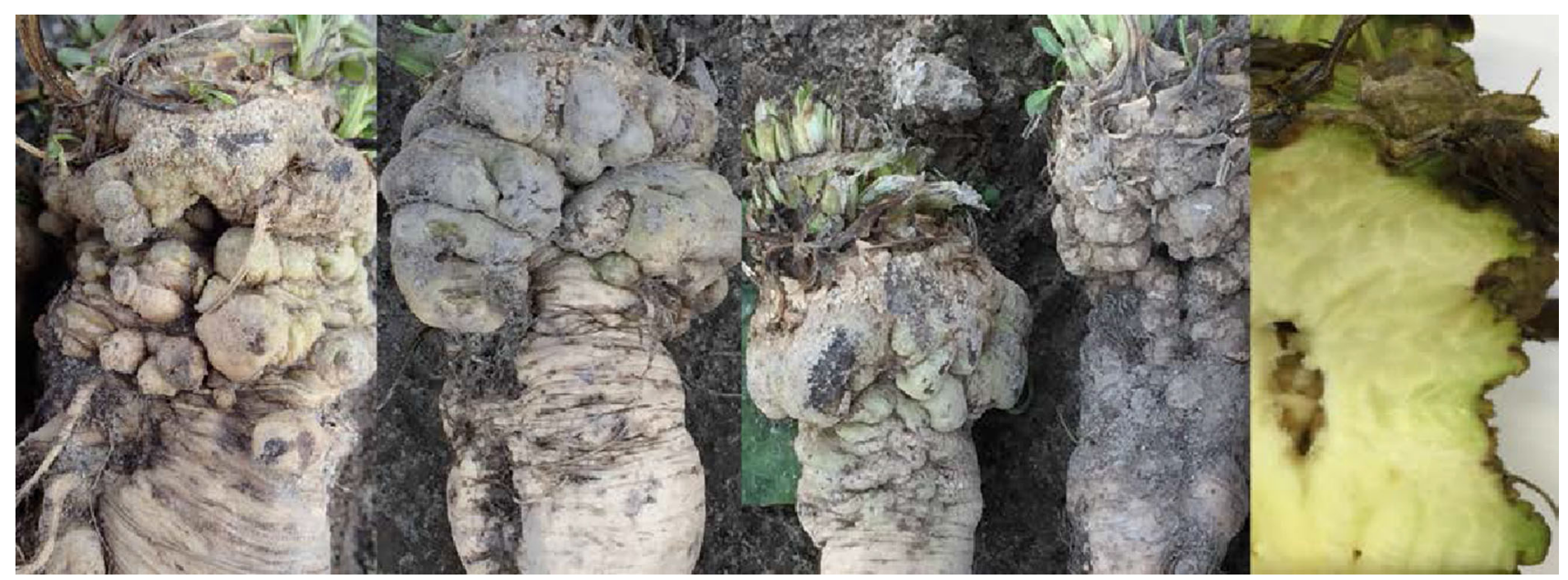

Fig. 2 Big galls observed on sugar beet roots, right — cross cut of the gall (Kłodawa, Poland)

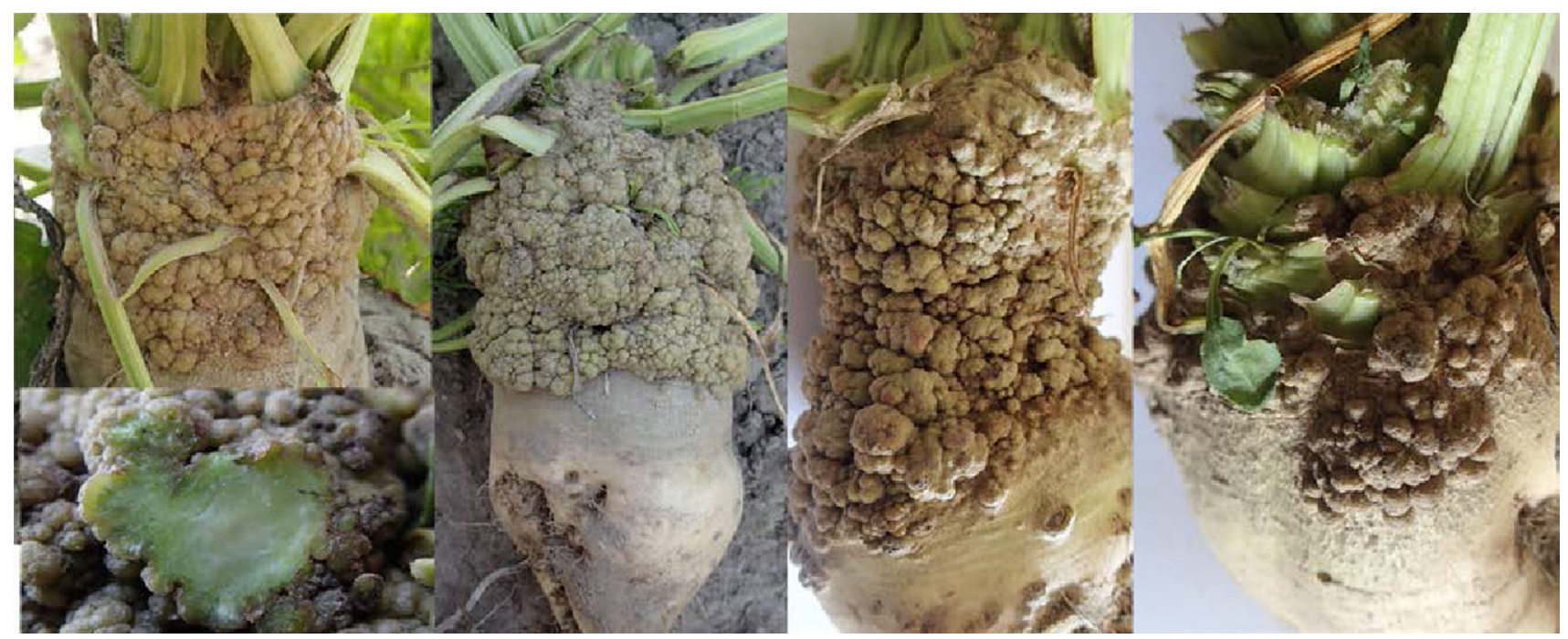

Fig. 3 Small galls observed on sugar beet roots, left down corner - cross cut of the gall (near Toruń, Poland)

Table 1 Yield quality of sugar beet roots with tubercle disease symptoms

\begin{tabular}{lllllllll}
\hline $\begin{array}{l}\text { Type of } \\
\text { roots }\end{array}$ & $\begin{array}{l}\text { Field } \\
\text { localization }\end{array}$ & $\begin{array}{l}\text { Sugar } \\
\text { content } \\
(\%)\end{array}$ & $\begin{array}{l}\mathrm{K} \quad \mathrm{Na} \\
(\mathrm{mmol} / \mathrm{kg})\end{array}$ & $\mathrm{N}-\alpha$ & $\begin{array}{l}\text { The theoretical sugar } \\
\text { yield by Reinefeld (\%) }\end{array}$ & $\begin{array}{l}\text { The theoretical sugar } \\
\text { yield by Buchholz }(\%)\end{array}$ & $\begin{array}{l}\text { Sugar content reduction } \\
\text { [Reinefeld/Buchholz] }(\%)\end{array}$ \\
\hline $\begin{array}{l}\text { Healthy } \\
\text { Diseased }\end{array}$ & Toruń & 16.49 & 50.5 & 5.7 & 21.3 & 14.07 & 14.22 & 12.98 \\
Healthy & Kłodawa & 15.47 & 63.2 & 7.8 & 23.2 & 12.53 & 15.55 & $1.54 / 1.24$ \\
\begin{tabular}{l} 
Diseased \\
\hline
\end{tabular} & 17.95 & 52.8 & 3 & 27.2 & 15.49 & 14.58 & - \\
\hline
\end{tabular}

beticola resulted in the supposition that the bacterium not exists. The results of our investigations, at best, led to the $X$. campestris pv. betae or Pantoea sp. described from sugar beet. The electronic source of StrainInfo http://www. straininfo.net/taxa/1676 does not contain X. beticola [29]. The List of Prokaryotic Names with Standing in Nomenclature (http://www.bacterio.net/) includes the nomenclature of prokaryotes and the nomenclatural changes as cited 
in the Approved Lists of Bacterial Names or validly published in the International Journal of Systematic Bacteriology (IJSB), or in the International Journal of Systematic and Evolutionary Microbiology (IJSEM), but there $X$. beticola is not listed. According to Bergey's Manual of Systematic Bacteriology [3]: Volume 2: The Proteobacteria, Part B: The Gammaproteobacteria, X. beticola is not a valid name. $X$. beticola was not listed in the first edition of Bergey's Manual of Systematic Bacteriology [13] and in phytobacteriology principles and practice by Janse [11].

\section{Xanthomonas beticola as a cause of pocket disease}

The described disease name in Poland is "tuberkuloza" and in the USA it refers to the description of a pocket disease-therefore we may consider those diseases to be the same $[6,10,25]$. The clear description of $X$. beticola disease can be found in Benada, Špaček and Šedivy manual of sugar beet pests and diseases printed in Poland in 1984. The bacterium is characterized as aerobic, Gram-negative, flagellate, non-sporulating rod with dimensions of $0.6-0.8 \times 1.5-2.0 \mu \mathrm{m}$. It can liquefy gelatin, curdle milk and create a yellow colony, reduce nitrates, and create indole on peptone broth with gelatin. It can also use number of sugars as the source of nourishment and produce acids. The optimal growth temperature is $29^{\circ} \mathrm{C}$, maximum $-39^{\circ} \mathrm{C}$ and minimum $-1.5^{\circ} \mathrm{C}$. Optimal $\mathrm{pH} 6.5$ but minimal $\mathrm{pH}$ is $4.5-4.8$ and maximal-9.0-9.5. The bacterium is not resistant to frost but easily can survive in the dry conditions. It can persist in the soil for long time maintaining pathogenic properties for even 14 years. The bacterium infects through wounds and prefers wet soils [2]. The disease is also described in very recent LIZ (Landwirtschaftlicher Informationsdienst Zuckerrübe) manuals (currently printed and online version) [16, 17], listed by APS [25] and by Streets [28], described by Sherf and MacNab [26] and by Lazarev [14]. The photograph of irregular galls attached to the sugar beet crown given by Cooke and Scott [5] is the most popular in the literature, and it is used in LIZ too [16, 17]. Cooke and Scott [5] gave the possibility to distinguish galls formed by A. tumefaciens by narrow tissue bridge from those formed by $X$. beticola by a bridge of tissue almost as wide as the gall and by contain internal cavities or pockets within the gall tissue. Lazarev [14] and Sherf and MacNab [26] described X. beticola (Smith, Brown, Townsend) Savelescu which causes tuberculosis of the table beet and the sugar beet as well as fodder beets. The disease occurs in the USA and is marked in the territories of the Russian Federation and also in Moldova, Georgia, Armenia, and Ukraine. The morphological and biochemical description of bacterium corresponds to this given by Benada et al. [2]. Additionally Lazarev [14] pointed that high temperature and the relative air humidity ( $90 \%$ and higher) favor the development of bacterial infections. He also gave information about the yield loss in favorable for the disease conditions. As he suggested, the percentage of diseased roots reaches even $17-21 \%$ in some years (data for Armenia), and in the diseased roots the sugar content is considerably reduced. Infected roots decay quickly under the influence of secondary infection. Control of the disease needs optimal agriculture, including crop rotation, cultivation of relatively resistant varieties, careful removal of plant residues, and treatment of seeds and plants with pesticides [14]. We have also found a note about Galach'yan [8] experiments which were carried out with naturally infected table beets and artificially infected fodder and sugar beets in 1956 in Armenia (USSR). They showed that sugar beet galls caused by $X$. beticola: cf. 38, 554 were seed-transmissible but only to $1.9-7 \%$ under field conditions. The infection also occurred through the soil, especially to injured roots.

\section{How long we know the pocket disease?}

Nyvall [22] described bacterial pocket disease in the USA (Colorado, Maryland, Michigan, New Mexico, Utah, Virginia, Wisconsin, and Wyoming). The disease was also called bacterial canker and was caused by $X$. beticola (Smith, Brown and Town) Burkh. He also paid attention to long periods for surviving in soil, entering roots through wounds at or near the crown level. Bacteria were distributed by any means that can move soil, such as irrigation water and machinery. The galls could develop just at the surface of the ground on the crown but might also occur on petioles and lower on the root. The central portion of the galls was water-soaked and yellow due to the presence of the bacteria. As the galls increased in the size, they became rough and fissured. The atypical information for the disease caused by $X$. beticola was that in the later stages of the disease an abnormal number of leaves were developed [22]. It is worth to noting that probably the first data on the tuberculosis of sugar beet occurred in the USA in the beginning of the XX century. Sugar beets collected in 1910-1912 in the USA showed at the crowns definite galls, which were thought to be crown galls (Agrobacterium galls), but many of these did not show the typical features of crown gall. Tumors were initiated by nodules and looked like cultivation wounds. Some of the galls were more or less smooth and globose, and looked much like the crown gall. When the galls were cut across there were brown areas inside, which could be traced for some distance in the interior. The causal organism that produced tubercles on sugar beets was named Bacterium beticolum in 1911 and the disease was named the bacterial pocket. In 1913 Serbinow described an organism that he called $B$. beticola (according to [4]). The B. beticola was a short motile rod, 
usually paired, but it could occur singly, in clumps, or in chains of 6-10 cells. The parasite presented a yellow color of the young bacterial colonies, which prevailed in most media. The bacterium was Gram-negative, reduced nitrates to nitrites, reduced methylene blue, produced no indole, and slowly liquefied gelatin. The organism was a wound parasite, which stimulated the tubercles to form discolored galls with cavities which usually contained the brown area with fluid. The tubercles with pockets were reproduced on sugar beets and garden beets by wound inoculation. Although in appearance the disease frequently resembled crown gall, it could be easily distinguished from it by cutting through the outgrowth and noting whether or not there were pockets and stained tissue within. In crown gall the tissue typically was white and sound. The disease was known to occur only in soil rich in nitrogenous fertilizers [4].

\section{Traces of Xanthomonas beticola in collections and researches}

The genus Xanthomonas contains phytopathogenic bacteria that are usually yellow pigmented on medium and can cause several diseases of worldwide distributed plants $[15,27]$. X. beticola is listed in collection of National Collection of Plant Pathogenic Bacteria (NCPPB [21]) there are two strains of the bacteria added to the collection in 1966. The strain X. beticola NCPPB No. 1831 was isolated in 1927 from Beta vulgaris in the USA by H.A. Elcock. The pathogenicity of bacteria was confirmed prior to initial freeze drying, but the culture's authenticity is not certain. These bacteria are considered probably not xanthomonad and the name is suggested as illegitimate (NCPPB [21]). Our correspondence with Ms. Charlotte Critchley and her verification of the authenticity of the collected strains by means of fatty acid profiling ensured us that both strains NCPPB 1831 and 1927 are viable, and they are Bacillus pumilus and not X. becticola (according the personal correspondence with Ms. Charlotte Critchley, National Collection of Plant Pathogenic Bacteria, Fera Science Ltd. in April 2016).

The trace in the investigations of the X. beticola was the list of Xanthomonas spp. in the article of Starr and Stephens [27] where it was clearly pointed out $-X$. beticola (ICPB XB 109Sm${ }^{r}$ ). The bacterium originated from the general stock culture collection of the Department of Bacteriology, University of California at Davis maintained for the International Collection of Phytopathogenic Bacteria (ICPB). The culture stock number leads on straight to the mistake. The number ICPB XB 109 currently belongs to $X$. campestris pv. betlicola - the host plant is Peper betle [19]. According to personal information, Starr's collection ended up at the University of California at Berkeley, most likely in Plant and Microbial Biology, formerly Plant Pathology (according to correspondence with prof. Richard M. Bostock Dept. of Plant Pathology, University of California and prof. Wolf-Dietrich Heyer University of California, Davis, 2016).

The next trace of $X$. beticola appeared in Ukraine, in 1984. Kozyrovskaya et al. [12] described properties of this pathogen and Agrobacterium tumefaciens. It also seems that $X$. beticola was used in test for searching antimicrobial properties of Bacillus pumilus by Kolomiets, Romanovskaya and Sverchkova [31]. In recent years nobody has seen pocket disease ("tuberkulez korneplodov" in Russian) in Russia, and old references tell that it was most harmful in Armenia (Ignatov 2016, personal communication).

The other xanthomonad associated with Beta vulgaris is $X$. campestris pv. betae, and it causes leafspot disease. Other known names for the strain are $X$. pv. betae or $X$. axonopodis pv. betae (http://www.straininfo.net/strains/ 23272).

We have found an atypical trace of $X$. beticola in Brazil-Lordello et al. [18] detected X. beticola var. $c y$ narae $\mathrm{n}$. var. in diseased plants of artichoke (Cynara scolimus L.) but no inoculation trial were made as an attempt to clear up the possible pathogenicity of them to Cynara scolimus.

\section{Pantoea agglomerans pv. betae as a cause of tubercle disease of sugar beet}

However, nowadays more often P. agglomerans pv. betae is considered the cause of this disease in Eastern Europe, especially Ukraine and Russia. Despite the fact that $P$. agglomerans was also isolated from the inner parts of the sugar beet roots with symptoms of rot (Ignatov 2016, personal communication), P. agglomerans is also recorded as a necrotizing pathogen of other plants, especially as recognized in Ukraine on soybean plants [23]. The problems which appear in the study of sugar beet pocket disease are due to the wide occurrence in nature of $P$. agglomerans and related species. Additionally it is present almost on all plants and follows other bacterial infections and diseases. As Ignatov stressed $P$. agglomerans contaminates about $25 \%$ of Xanthomonas spp. and Pseudomonas spp. isolates, but only $10 \%$ of these isolates show hypersensitive response on tested plants and even smaller number have high virulence on host plants. This experience showed him strict dependence of $P$. agglomerans diseases on environment and host reactions, e.g., some pathogenic $P$. agglomerans can occur at temperature above $25^{\circ} \mathrm{C}$ and on particular host plant only (Ignatov 2016, personal communicate). The opinion is confirmed by a study of Manulis and Barash [20]. They described P. agglomerans pv. betae as a parasite of sugar beet. The bacterium was a Gram-negative, non-capsulated, 
non-spore-forming, predominately motile rod. It was able to form galls at wound sites, mainly in the crown region of the stem. The hosts of P. agglomerans pv. betae was Beta vulgaris and Gypsophila paniculata. They described also $P$. agglomerans pv. gypsophilae which was pathogenic only on gypsophila but elicited a hypersensitive response on beet. The virulence genes necessary to transform this epiphytic bacterium into the plant pathogen and interactions with the host components have not yet been completed. The biosynthetic pathways for IAA and cytokinin were recognized in $P$. agglomerans pv. betae. Inactivation of IAA and cytokinin biosynthesis pathways caused a reduction in gall size but did not eliminate gall initiation. Complete inhibition of galls was achieved by mutations in the hrp gene cluster indicating that type III effectors are crucial for gall formation. Observations could suggest that the mode of pathogenic activity was due to the plasmid (pPATH), hrp genes cluster, virulence effectors type III and phytohormones produced by both pathogen and host plant, because the growth regulators synthesized by the plant in response to elicitation caused by type III effectors are responsible for gall initiation [7, 20, 30]. The newest data emphasized that crucial for gall formation are phytohormones which are secreted by host plant. The ones produced by pathogen are not absolutely required for gall formation [1]. For diseases control, the use of pathogenic-free transplants and sanitation is suggested [1, 20]. Manulis and Barash [20] and Barash and Manulis-Sasson [1] also pointed out that no resistant cultivars are available, but mobilizing $p t h G$ (pathogenicity gene on gypsophila) into P. agglomerans pv. betae (in trans) can cause that the beet pathovar will induce a hypersensitive response instead of galls on beet. The function of PthG protein as an Avr protein on beet suggests that this host may possess a resistance gene that recognizes PthG protein. The hypersensitive response was also recognized in other beet species, which suggests that the resistance protein is conserved throughout the genus. The result of economic loss for table beets is that they cannot be processed mechanically [1], but no data concerning the quality of the yield of sugar beets are available.

\section{Tumors on sugar beet roots caused by Bradyrhizobium betae sp. nov}

Rivas et al. [24] isolated several endophytic slow-growing bacterial strains from tumors of two deformed plants. Phylogenetic analysis of the DNA regions coding $16 \mathrm{~S}$ rRNA revealed that these strains belonged to the genus Bradyrhizobium. Sequence analysis of the $16 \mathrm{~S}-23 \mathrm{~S}$ rDNA intergenic spacer region indicated that these novel strains formed a homogeneous group different from all Bradyrhizobium species previously described. This genus currently includes four species able to produce nodules in several legumes. Rivas et al. [24] suggested, according to phenotypic and molecular taxonomic approaches, that these strains represent a novel species of Bradyrhizobium phylogenetically similar to $B$. japonicum. They proposed the name $B$. betae sp. nov. for the novel species of Bradyrhizobium.

\section{Tumors on sugar beet roots caused by Urophlyctis leproides (Physoderma leproides)}

Sugar beet crown wart disease develops as an effect of infestation Beta vulgaris by Urophlyctis leproides (Physoderma leproides). Symptoms of the disease are crown and root warts [10]. It was first reported in Algeria in 1894 and since then, the disease has been recorded in Argentina, Italy, Spain, United Kingdom, Palestine and the USA [9]. In Egypt, the disease was observed during harvest in 2003, 2004 and 2005 at three locations in the Nile Delta on different sugar beet cultivars. Disease incidence started from $1 \%$ in 2003 reaching $1-2 \%$ in 2004 and $3 \%$ in 2005. The disease exhibited typical symptoms on root crowns and occasionally on petioles and leaf blades. Affected leaves were malformed showing galls on leaf blades and petioles, galls were greenish brown with a rough appearance. Galls on crowns range the size from $1 \mathrm{~cm}$ to $8-10 \mathrm{~cm}$. These galls were spherical, colored green through yellow to brown depending on the age of plant. The surface of tumors was rough and attached to the host by a narrow base. They occurred singly or in complexes. Sections made through a crown gall revealed cavities filled with thick-walled sporangia (resting spores) surrounded by thickened wall. Sporangia were light brown, spherical to ovoid or concave. Resting sporangia are released into the soil when galls are decomposed, and then they could be detected in the soil. Gouda and Emeran [9] demonstrated that Koch's postulates were fulfilled for the pathogen. Symptoms of the disease appeared on the infested plants after 11 days with no symptoms on uninoculated control plants. Finally sporangia were reisolated from the mature galls' tissues [9].

\section{Conclusion}

Concluding we should point out that there are several possibilities to recognize tumor-like disease symptoms which are typically classified as Agrobacterium galls or Xanthomonas tubercles. There is no simple way to recognize the proper causal organism in the field condition especially since $P$. agglomerans is involved in the development of gall symptoms on sugar beet roots. Studying the descriptions of tubercle disease/tuberculosis/pocket disease of sugar beet there appears a feeling that various diseases described over the years as one and the same disease were 
probably caused by various pathogens or they were caused by mixed organisms. We suppose that $X$. beticola does not exist and the description of the disease has been repetitively copied for many years until now. Since we noticed the disease in Poland, in the nearest future a problem seems to arise, especially due to mild winters, and because of it we have to take careful observations of sugar beet fields and continue research programs.

Open Access This article is distributed under the terms of the Creative Commons Attribution 4.0 International License (http://crea tivecommons.org/licenses/by/4.0/), which permits unrestricted use, distribution, and reproduction in any medium, provided you give appropriate credit to the original author(s) and the source, provide a link to the Creative Commons license, and indicate if changes were made.

\section{References}

1. Barash I, Manulis-Sasson S (2009) Recent evolution of bacterial pathogens: the gall-forming Pantoea agglomerans case. Annu Rev Phytopathol 47:133-152

2. Benada J, Špaček J, Šedivy J (1984) Atlas chorób i szkodników buraka. PWRiL, Warszawa

3. Brenner DJ, Krieg NR, Staley JT, Garrity GM (2005) Bergey's manual of systematic bacteriology. In: Garrity G, Brenner DJ, Krieg NR, Staley JR (eds) The proteobacteria, part B: the gammaproteobacteria. Springer, East Lansing, p 1106

4. Brown NA (1928) Bacterial pocket disease of the sugar beet. J Agric Res 37(3):155-168

5. Cooke DA, Scott JE (1993) The sugar beet crop. Science to practice. Chapman \& Hall, London

6. Drycott AP (2006) Sugar beet. Blackwell Publishing Ltd, Oxford

7. Ezra D, Barash I, Valinsky L, Manulis S (2000) The dual function in virulence and host range restriction of a gene isolated from the $\mathrm{pPATH}_{\text {Ehg }}$ plasmid of Erwinia herbicola pv. gypsophilae. Mol Plant Microbe Interact 13(6):683-692

8. Galach'yan RM (1961) The ways of infection of beet gall. In: Panosyan AK (ed) Problems of microbiology. I. [Voprosy mikrobiologii. I.] Mikrobiol. Sborn. Akad. Nauk. Armyan. Akad. Nauk Armyan. S.S.R., S.S.R. Erevan, pp 41-52

9. Gouda MI, Emeran AA (2006) First report of sugar beet crown wart disease caused by Urophlyctis leproides in Egypt. New Disease Reports 13:39

10. Harveson RM, Hanson LE, Hein GL (eds) (2009) Compendium of beet diseases and pests, 2nd edn. APS Press, St. Paul

11. Janse JD (2005) Phytobacteriology principles and practice. CABI Publishing, Wallingford

12. Kozyrovskaya NA, Gvozdyak RI, Muras VA, Kordyum VA (1984) Changes in properties of phytopathogenic bacteria effected by plasmid pRD1. Arch Microbiol 137(4):338-343

13. Kreig NR, Holt JG (eds) (1984) Bergey's manual of systematic bacteriology, vol 1. Williams \& Wilkins, Baltimore

14. Lazarev AM (2009) Xanthomonas beticola. Interactive agricultural ecological atlas of Russia and neighboring countries. Economic plants and their diseases, pests and weeds. http://www. agroatlas.ru/en/content/diseases/Beta_alba/Beta_alba_Xanthomo nas_beticola/. Accessed 14 Mar 2016

15. Lee YA, Sung AN, Liu TF, Lee YS (2009) Combination of chromogenic differential medium and estA-specific PCR for isolation and detection of phytopathogenic Xanthomonas spp. Appl Environ Microbiol 75(21):6831-6838

16. LIZ manuals on-line version (2016) Landwirtschaftlicher Informationsdienst Zuckerrübe. www.int-koop.de/schaeden/mod_liz_ schaeden_texttafel/tafel_id/128/partner/bs/lang/en/index.html, http://schaeden.rheinmedia.de/cgibin/schaedlinge_details.cgi? funktion=druckansicht\&id=128\&sprache=gb\&partner=bs. Accessed 14 Mar 2016

17. LIZ-Landwirtschaftlicher Informationsdienst Zuckerrübe (2005) Burak cukrowy choroby i uszkodzenia, szybkie rozpoznanie. Betmor-Wydawnictwo Waldemar Kostrzewa, Poznań (in Polish: Sugar beet, diseases and injuries, a quick method of identification)

18. Lordello LGE, Joly S, Campos HR, Camargo L de S (1961) Nematódeos e bactérias em fôlhas de alcachôfra. An Esc Super Agric Luiz de Queiroz 18: 243-249. doi:10.1590/S007112761961000100015. Accessed 9 Apr 2016

19. Mahesha L, Nadugala NS, Amarasinghe BHRR (2009) Diversity among different isolates of Xanthomonas campestris pv. betlicola on the basis of phenotypic and virulence characteristics. J Natl Sci Found Sri Lanka 37(1):77-80

20. Manulis S, Barash I (2003) Pantoea agglomerans pvs. gypsophilae and betae, recently evolved pathogens? Mol Plant Pathol 4(5):307-314

21. NCPPB-National Collection of Plant Pathogenic Bacteria (2016) Xanthomonas beticola. http://ncppb.fera.defra.gov.uk/fur therinfo.cfm?ncppb_no=1927, http://ncppb.fera.defra.gov.uk/fur therinfo.cfm?ncppb_no=1831. Accessed 9 Apr 2016

22. Nyvall RF (1989) Field crop diseases handbook. Springer, Van Nostrand Reinhold, New York

23. Patyka W, Gnatiuk T, Zhytkevych N, Kalinichenko A, Frączek K (2015) Occurrence of the pathogenic bacteria Pantoea agglomerans in soybean cultivation. [Występowanie bakterii fitopatogenicznej Pantoea agglomerans w uprawie soi]. Prog In Plant Protect 55(3):280-285

24. Rivas R, Willems A, Palomo JL, Garcia-Benavides P, Mateos PF, Martinez-Molina E, Gillis M, Velazquez E (2004) Bradyrhizobium betae sp. nov., isolated from roots of Beta vulgaris affected by tumour-like deformations. Int $\mathrm{J}$ Syst Evol Microbiol 54:1271-1275

25. Ruppel EG (2016) Diseases of beet (Beta vulgaris L.), last update 4/8/03, APS-The American Phytopathological Society. http:// www.apsnet.org/publications/commonnames/Pages/Beet.aspx. Accessed 9 Apr 2016

26. Sherf AF, MacNab AA (1986) Vegetable diseases and their control, 2nd edn. John Wiley \& Sons, New York

27. Starr MP, Stephens WL (1964) Pigmentation and taxonomy of the genus Xanthomonas. J Bacteriol 87(2):293-302

28. Streets RB (1984) The diagnosis of plant diseases: a field and laboratory manual emphasizing the most practical methods for rapid identification. Eight printing, The University of Arizona Press, Tucson

29. Verslyppe B, De Smet W, De Baets B, De Vos P, Dawyndt P (2014) StrainInfo introduces electronic passports for microorganisms. Syst Appl Microbiol 37(1):42-50

30. Weinthal DM, Barash I, Panijel M, Valinsky L, Gaba V, ManulisSasson S (2007) Distribution and replication of the pathogenicity plasmid pPATH in diverse populations of the gall-forming bacterium Pantoea agglomerans. Appl Environ Microbiol 73(23):7552-7561

31. Zaikov GE (ed) (2008) Biotechnology: state of the art and prospects for development. Nova Science Publishers, New York 